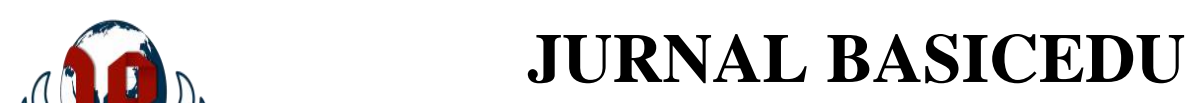

Volume 5 Nomor 3 Tahun 2021 Halaman 1532-1538

Research \& Learning in Elementary Education https://jbasic.org/index.php/basicedu

PAHLAWAN

\title{
Pengaruh Komunikasi Guru Dan Orang Tua Terhadap Kemampuan Membaca Permulaan Siswa di Sekolah Dasar
}

\author{
Siti Walimah \\ Pendidikan Dasar, Universitas Terbuka, Indonesia \\ E-mail: Sitiwalimah71@gmail.com
}

\begin{abstract}
Abstrak
Tujuan penelitian ini adalah untuk mengetahui pengaruh komunikasi guru dan orang tua secara bersamasama terhadap kemampuan membaca permulaan, pengaruh komunikasi guru terhadap kemampuan membaca permulaan, dan pengaruh komunikasi orang tua terhadap kemampuan membaca permulaan pada siswa Kelas 1 SDN Wilayah V Kecamatan Kalideres. Responden dalam penelitian ini berjumlah 100 siswa.Metode penelitian yang digunakan adalah metode survei dengan tiga variabel yaitu Komunikasi guru (X1), Komunikasi orang tua (X2), dan Kemampuan membaca permulaan (Y). Hasil penelitian menunjukan: 1)Terdapat pengaruh yang signifikan komunikasi guru dan komunikasi orang tua secara bersama-sama terhadap kemampuan membaca permulaan siswa Kelas 1 SDN Wilayah V Kecamatan Kalideres. Hal ini dibuktikan dengan perolehan nilai Sig. $0.000<0.05$ dan $\mathrm{Fh}=11.203$. 2) Terdapat pengaruh yang signifikan komunikasi guru terhadap kemampuan membaca permulaan siswa Kelas 1 SDN Wilayah V Kecamatan Kalideres. Hal ini dibuktikan dengan perolehan nilai Sig. $0.097<0.05$ dan th $=3.524$. 3) Terdapat pengaruh yang signifikan komunikasi orang tua terhadap kemampuan membaca permulaan siswa Kelas 1 SDN Wilayah V Kecamatan Kalideres. Hal ini dibuktikan dengan perolehan nilai Sig. $0.028<0.05$ dan th $=2.224$.

Kata Kunci: kemampuan membaca permulaan, komunikasi guru, komunikasi orang tua.
\end{abstract}

\begin{abstract}
The aim of this study was to determine the effect of teacher and parent communication together on the student's ability of early reading, the influence of teacher communication on the student's ability of early reading, and the effect of parent communication on the student's ability of early reading of the 1st grade students of SDN Wilayah V Kecamatan Kalideres. The research method used was a survey method with three variables. The results showed: 1) There is a significant effect of teacher and parent communication together on the student's ability of early reading. This is evidenced by the acquisition of the Sig. $0.000<0.05$ and Fh $=11.203$. 2) There is a significant influence of teacher communication on the student's ability of early reading.This is evidenced by the acquisition of the Sig. $0.097<0.05$ and th $=3.524 .3$ ) There is a significant effect of parent communication on the student's ability of early reading of the 1st grade students of SDN Wilayah V Kecamatan Kalideres. This is evidenced by the acquisition of the Sig. $0.028<0.05$ and th $=2.224$. Keywords: the student's ability of early reading, parent communication, teacher communication.
\end{abstract}

Copyright (c) 2021 Siti Walimah

Corresponding author :

Email : Sitiwalimah71@gmail.com

DOI : https://doi.org/10.31004/basicedu.v5i3.966 
1533 Pengaruh Komunikasi Guru Dan Orang Tua Terhadap Kemampuan Membaca Permulaan Siswa di Sekolah Dasar-Siti Walimah

DOI : https://doi.org/10.31004/basicedu.v5i3.966

\section{PENDAHULUAN}

Diketahui dalam PIRLS pada tahun 2011 International Results in Reading, Negara Indonesia memasuki peringkat ke-45 dari 48 negara peserta dengan skor yang diperolah 428 dari skor rata-rata 500 (Iii \& Penelitian, 2015). Selain itu pada uji PISA di tahun 2009 peserta didik Indonesia berada pada peringkat ke-57 dengan skor 396 (nilai rata-rata OECD 493), kurang lebih 65 negara ikut serta dalam PISA 2009 DAN 2012. Jadi posisi negara Indonesia berada pada urutan terendah untuk minat bacanya di bandingkan dengan negaranegara lainnya (Hidayah, 2017).

Membaca memiliki peranan penting dalam belajar. Keterampilan membaca merupakan keterampilan utama dalam belajar karena membaca dapat membuat siswa memperoleh ilmu pengetahuan, perkembangan daya nalar, sosial dan emosional (Rumidjan et al., 2017). Membaca merupakan pondasi utama dalam mengembangkan ilmu pengetahuan. Siswa yang menagalami kesulitan dalam membaca tentunya akan membuat siswa sulit untuk menguasai semua mata pelajaran dan mengikuti seluruh proses belajar siswa di SD (Rahman \& Yogyakarta, 2014). Pada siswa tingkat dasar, membaca permulaan perlu dilatih dan dibiasakan. Membaca permulaan merupakan tahap awal membaca atau proses visual (Tjoe, 2013). Berdasarkan hasil observasi dan wawancara yang dilakukan peneliti dengan guru kelas 1 SD di SDN Wilayah V Kecamatan Kalideres terhadap proses pembelajaran di kelas ditemukan bahwa kemampuan membaca permulaan siswa masih rendah. Hal ini dapat dilihat dari siswa yang memiliki nilai kemampuan membaca permulaan di atas Kriteria Ketuntasan Minimal (KKM) yaitu berjumlah 30\%. Permasalahan tersebut disebabkan karena banyak siswa yang mengalami kesulitan dalam pengucapan huruf konsonan pada saat membaca permulaan. Mereka mengalami kesulitan dalam mengucapkan huruf konsonan, misalnya huruf f, v, p, dan r. Selain itu, bentuk kesulitan membaca permulaan yang dialami siswa yaitu sulit dalam membedakan huruf $\mathrm{p}$ dan $\mathrm{q}, \mathrm{b}$ dan $\mathrm{d}$, dan sebagainya. Faktor kesulitan tersebut membuat siswa mengalami kesulitan dalam merangkai huruf dan membaca menjadi terbata-bata apabila ditambakan dengan huruf vokal. Membaca permulaan siswa harus mampu melafalkan huruf konsonan dengan benar, seperti huruf b, d, k, l, m, p, s, dan t. Huruf-huruf konsonan ini ditambahkan dengan huruf vokal yang akhirnya digunakan sebagai indikator kemampuan membaca permulaan, sehingga menjadi a, b, d, e, I, k, l, m, o, p, s, t, dan u (Rachmawati \& N, 2020). Selain permasalahan di atas, faktor yang membuat siswa tidak mampu mencapai tujuan pembelajaran dalam membaca permulaan yaitu kurangnya peranan komunikasi guru dan orang tua. Komunikasi yang efektif dalam pembelajaran ditentukan oleh adanya keaktifan belajar dan adanya timbal balik dalam menjawab pertanyaan, baik secara fisik maupun mental (Wisman, 2017). Jadi, komunikasi guru dan orang tua terhadap siswa penting dilakukan dalam mencapai tujuan pembelajaran. Keikutsertaan guru, orang tua dan siswa dalam membangun pendidikan yang kreatif dan inovatif dapat memberikan hasil pendidikan yang optimal (Triwardhani et al., 2020).

Peranan komunikasi guru dan orang tua memiliki pengaruh yang cukup kuat terhadap kemampuan membaca permulaan siswa SD kelas 1. Komunikasi guru merupakan suatu kegiatan yang dilakukan dalam berbagi informasi baik dari suatu tempat, orang maupun kelompok (Vinet \& Zhedanov, 2011). Dalam membangun komunikasi yang efektif, guru dituntut untuk mampu menciptakan iklim mengajar yang kondusif, serta dapat memotivasi siswa untuk belajar. Adanya komunikasi yang baik yang dilakukan guru apabila ada timbal balik (feedback) antara subjek dan objek dalam pembelajaran (Nurma Annisa Azzahra, Hardika, 2019). Tidak hanya guru, keterlibatan orang tua siswa pun sangat berperan aktif dalam mewujudkan tujuan pendidikan. Apabila orang tua dan anak memiliki hubungan dekat dan komunikasi yang baik, maka keduanya akan tercipta saling memahami keinginan serta harapan dari masing-masing pihak, sehingga apa yang menjadi keputusan bersama tercapai (Program et al., 2014). Keikutsertaan orang tua dalam menciptakan komunikasi yang intesif dengan guru dapat membantu mencapai tujuan dan fungsi dari sekolah. Dalam meningkatkan keterampilan membaca diperlukan adanya pembiasaan kegiatan literasi(Pedagogik, 2020). Dalam kegiatan 
1534 Pengaruh Komunikasi Guru Dan Orang Tua Terhadap Kemampuan Membaca Permulaan Siswa di Sekolah Dasar-Siti Walimah

DOI : https://doi.org/10.31004/basicedu.v5i3.966

literasi di rumah, diperlukan adanya komunikasi siswa dengan orang tua, sehingga siswa dapat terlatih dan terbiasa melakukan kegiatan literasi yang dapat meningkatkan keterampilan membaca siswa. Berdasarkan hasil observasi yang dilakukan peneliti melalui guru kelas 1 SD bahwa penyebab rendahnya kemampuan membaca permulaan siswa disebabkan kurangnya komunikasi guru dan orang tua. Banyak orang tua yang tidak memberikan perhatian dalam melihat perkembangan belajar anak di rumah, tidak menciptakan kondisi belajar di rumah dengan baik, tidak memberikan bimbingan anak dalam belajar, fasilitas belajar yang kurang memadai dan kurangnya motivasi belajar yang dilakukan oleh orang tua. Selain itu, guru tidak melakukan komunikasi yang rutin kepada orang tua terhadap perkembangan belajar anak di sekolah.

Oleh karena itu, peranan komunikasi guru dan orang tua sangat dibutuhkan dalam meningkatkan kemampuan belajar membaca anak, terutama dalam membaca permulaan. Proses membaca dimulai dengan kemampuan membaca permulaan(Rachmawaty, 2017). Komunikasi yang rutin antara guru dan orang tua dapat mempengaruhi perkembangan belajar membaca permulaan anak dengan baik. Komunikasi guru dan orang tua dapat dilakukan dengan cara mendampingi dan membimbing anak pada saat membaca permulaan yaitu memperhatikan kemampuan anak dalam mengenal simbol-simbol atau lambang huruf. Membaca permulaan merupakan tahap awal proses membaca atau proses visual (Tjoe, 2013).Bentuk komunikasi guru dan orang tua dalam meningkatkan kemampuan membaca permulaan yaitu dengan cara memfasilitasi belajar anak yang memadai, sehingga tercipta suasana rumah dan sekolah yang tenang serta tentram yang dapat membuat anak betah dan bersemangat dalam belajar. Membelikan perlengkapan belajar untuk anak sangat penting karena perlengkapan belajar merupakan sumber belajar anak. Semakin banyak sumber belajar anak, semakin baik bagi anak dalam memperkaya pengetahuan atau melatih anak dalam membaca. Selanjutnya, guru memberitahu bagaimana mengatur jadwal kegiatan belajar anak. Belajar di rumah harus selalu ditanamkan agar anak bisa belajar secara teratur dan terencana. Langkah terakhir, guru dapat memberitahu langkah-langkah yang harus dilakukan oleh orang tua dalam mengatasi permasalahan belajar anak. Orang tua harus dapat mengetahui kemampuan belajar yang dimiliki oleh anaknya, sehingga orang tua dapat mengarahkan cara belajar yang tepat untuk anaknya. Adanya komunikasi yang baik antara guru dan orang tua akan menghasilkan individu yang senantiasa mempunyai semangat positif dalam belajar dan membantu dalam memecahkan permasalahan yang dihadapi siswa.

Tujuan penelitian ini adalah sebagai berikut (1) untuk mengetahui pengaruh positif komunikasi guru terhadap kemampuan membaca permulaan siswa SD kelas 1; (2) untuk mengetahui pengaruh positif komunikasi orang tua terhadap kemampuan membaca permulaan siswa SD kelas 1; (3) untuk mengetahui komunikasi guru dan orang tua terhadap kemampuan membaca permulaan siswa SD kelas 1.

\section{METODE}

Metode yang digunakan dalam penelitian ini yaitu metode survei. Metode ini merupakan penelitian untuk penelitian kuantitatif, yaitu menggunakan pertanyaan yang sama pada setiap individu yang diteliti. Setelah itu, peneliti mencatat, mengolah dan menganalis semua jawaban dari individu. Metode survei merupakan metode yang mampu membuat tafsiran yang akurat tentang karakteristik-karakteristik keseluruhan populasi. Ada tiga varibel yang akan diteliti dalam penelitian ini, yaitu dua variabel bebas (Independent Variabel) dan satu variabel terikat (Variable Dependent)(Marina, 2015). Varibale bebas (Independent Variable) yaitu: Komunikasi Guru (X1) dan Komunikasi Orang Tua (X2), sedangkan variabel terikatnya (Dependent Variable) adalah Kemampuan Membaca Siswa (Y). Penelitian ini menggunakan teknik analisis korelasi dan regresi, yaitu mencari hubungan dan pengaruh antara dua variabel bebas (Indevendent Variable) dan satu variabel terikat (Dependent Variable). 
1535 Pengaruh Komunikasi Guru Dan Orang Tua Terhadap Kemampuan Membaca Permulaan Siswa di Sekolah Dasar-Siti Walimah

DOI : https://doi.org/10.31004/basicedu.v5i3.966

Populasi merupakan subjek atau objek yang memiliki kualitas atau karakteristik tertentu, kemudian peneliti menarik kesimpulan (Marina, 2015). Populasi penelitian ini adalah seluruh siswa kelas SDN Tegal Alur 01 yang berjumlah 390 siswa, SDN Tegal Alur 02 berjumlah 210, dan SDN Tegal Alur 4 berjumlah 300.

Teknik pengambilan sampel dilakukan secara random sampling atau pemilihan sampel secara acak sederhana. Sample merupakan bagian dari populasi (Susilana, 2015). Adapun hasil simpel random sampling yang akan di teliti yaitu SDN Tegal Alur 01 dengan jumlah siswa 30 orang, SDN Tegal Alur 02 kelas A 30 orang, dan SDN Tegal Alur 04 kelas B 40 orang. Dalam penelitian ini menggunakan skala likert. Skala likert digunakan untuk mengukur sikap, pendapat atau sekelompok orang tentang fenomena social (Iii \& Penelitian, 2015).

Teknik pengumpulan data yang digunakan dalam penelitian ini adalah menggunakan kueisioner/angket. Kuesioner/angket dan tes lisan digunakan dalam penelitian untuk menjaring data tentang komunikasi guru dan orang tua.

\section{HASIL DAN PEMBAHASAN}

Tabel 1. Hasil Perhitungan Pengujian Koefisien Korelasi Ganda Variabel $X_{1}$ dan $X_{2}$ terhadap $Y$

\begin{tabular}{c|c|c|c|c|}
\multicolumn{4}{c|}{ Model Summary } \\
\cline { 2 - 5 } Model & R & R Square & $\begin{array}{c}\text { Adjusted R } \\
\text { Square }\end{array}$ & Std. Error of the Estimate \\
\hline 1 & $.433^{\mathrm{a}}$ & .188 & .171 & 8.57684 \\
\hline
\end{tabular}

a. Predictors: (Constant), Komunikasi Orang Tua, Komunikasi Guru

Berdasarkan tabel 1. Nilai R sebesar 0.433 menunjukkan adanya pengaruh antara komunikasi orang tua dan guru terhadap kemampuan membaca permulaan dengan koefesien determinasi yang dihasilkan sebesar 0.188. Dengan demikian, variabel komunikasi orang tua dan guru memberikan pengaruh perubahan kemmapuan membaca permulaan sebesar 18.8\%. Oleh karena itu, dapat disimpulkan bahwa variabel komunikasi guru dan orang tua dapat digunakan sebagai prediktor terhadap kemampuan membaca permulaan. Sedangkan standart kesalahan estimasi adalah 8.57684. Hal ini disebabkan karena kedua variabel yang menjadi prediktor terhadap kemampuan membaca permulaan tidak semuanya memberikan pengaruh yang besar secara bersama-sama. Jadi, dapat dikatakan bahwa hipotesis yang menjelaskan komunikasi orang tua dan guru dapat digunakan sebagai prediktor terhadap kemampuan membaca permulaan diterima.

Tabel 2. Hasil Perhitungan Pengujian Signifikansi Koefisien Regresi Variabel X1 dan X2 terhadap Y

\begin{tabular}{lllcccr} 
& Model & $\begin{array}{c}\text { Sum of } \\
\text { Squares }\end{array}$ & df & Mean Square & F & Sig. \\
\hline 1 & Regression & 1648.227 & 2 & 824.114 & 11.203 & $.000^{\mathrm{b}}$ \\
& Residual & 7135.533 & 97 & 73.562 & & \\
& Total & 8783.760 & 99 & & &
\end{tabular}

a. Dependent Variable: Kemampuan Membaca Permulaan

b. Predictors: (Constant), Komunikasi Orang Tua, Komunikasi Guru

Dari tabel 2. dapat dinyatakan bahwa terdapat pengaruh yang signifikan komunikasi guru dan komunikasi orang tua secara bersama- sama terhadap kemampuan membaca permulaan. Hal ini dibuktikan dengan perolehan nilai Sig. 0,000 $<0,05$ dan $\mathrm{Fh}=11.203$. Hal ini menunjukan bahwa Ho ditolak dan $\mathrm{H}_{1}$ diterima. Artinya, terdapat pengaruh yang signifikan komunikasi orang tua dan guru secara bersama-sama terhadap kemampuan membaca permulaan. 

Sekolah Dasar-Siti Walimah

DOI : https://doi.org/10.31004/basicedu.v5i3.966

Tabel 3. Hasil Perhitungan Persamaan Regresi Ganda Variabel X1 dan X2 terhadap Y

Coefficients

\begin{tabular}{|c|c|c|c|c|c|c|c|c|c|c|c|}
\hline \multirow{2}{*}{\multicolumn{2}{|c|}{ Model }} & \multicolumn{2}{|c|}{$\begin{array}{l}\text { Unstandardize } \\
\text { d } \\
\text { Coefficients }\end{array}$} & \multirow{2}{*}{$\begin{array}{l}\begin{array}{l}\text { Standard } \\
\text { ized } \\
\text { Coefficie } \\
\text { nts }\end{array} \\
\qquad \text { Beta }\end{array}$} & \multirow[b]{2}{*}{$\mathbf{t}$} & \multirow[b]{2}{*}{ Sig. } & \multicolumn{3}{|c|}{ Correlations } & \multicolumn{2}{|c|}{$\begin{array}{l}\text { Collineari } \\
\text { ty } \\
\text { Statistics }\end{array}$} \\
\hline & & & $\begin{array}{l}\text { Std. } \\
\text { Erro }\end{array}$ & & & & $\begin{array}{l}\text { Zero } \\
-\end{array}$ & & & & \\
\hline 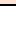 & (Constant) & 29.897 & 11.093 & & 2.695 & .008 & & & & & \\
\hline & $\begin{array}{l}\text { Komunikas } \\
\text { i Guru }\end{array}$ & .341 & .097 & .332 & 3.524 & .001 & .382 & .337 & .322 & .943 & 1.061 \\
\hline & $\begin{array}{l}\text { Komunikasi } \\
\text { Orang Tua }\end{array}$ & .241 & .109 & .210 & 2.224 & .028 & 289 & 220 & .204 & .943 & 1.061 \\
\hline
\end{tabular}

a. Dependent Variable: Kemampuan Membaca Permulaan

Dari tabel 3. dapat dinyatakan bahwa terdapat pengaruh yang signifikan komunikasi guru terhadap kemampuan membaca permulaan. Hal ni dibuktikan dengan perolehan nilai Sig. $0.097<0.05$ dan th $=3.524$ dan nilai Sig. $0.028<0.05$ dan th $=2.224$. Adapun kontribusi variabel komunikasi guru terhadap kemampuan membaca permulaan dapat dinyatakan dengan rumus: $\mathrm{KD}=$ Nilai $\beta_{x 1 y} \mathrm{x}$ Nilai Korelasi Pasialnya $\left(r_{x 1 y}\right) \times 100 \% \mathrm{KD}=0.341 \times 0.337 \times 100 \%=11.4 \%$. Dari hasil perhitungantersebut dapat dinyatakan bahwa kontribusi komunikasi guru dalam meningkatkan kemampuan membaca permulaan sebesar $11.4 \%$. Adapun kontribusi variabel komunikasi orang tua terhadap kemampuan membaca permulaan dapat dinyatakan dengan rumus: $\mathrm{KD}=$ Nilai $\beta x 2 y$ x Nilai Korelasi Pasialnya $(r x 2 y) \times 100 \% \mathrm{KD}$ $=0.241 \times 0.220 \times 100 \%=5.30 \%$. Dari hasil perhitungan tersebut dapat dinyatakan bahwa kontribusi komunikasi orang tua dalam meningkatkan kemampuan membaca permulaan sebesar $5.30 \%$.

Dalam penelitian ini, dapat diketahui bahwa komunikasi guru dan orang tua terhadap membaca permulaan meningkat, dengan kata lain bahwa komuniasi guru dan orang tua sangat erat kaitannya dengan membaca permulaan. Apabila komunikasi guru dan orang tua dengan siswa kurang, maka membaca permulaan siswa tidak mudah dikuasai, karena mereka sangat saling mempengaruhi. Oleh karena itu, komunikasi guru dan orang tua merupakan salah satu faktor yang dapat mempengaruhi kemampuan membaca permulaan siswa. Hal ini sejalan dengan Penelitian dengan judul "Pengaruh Komunikasi Orang Tua dan Guru Terhadap Prestasi Belajar Anak" pada Gampong Ujong Tanoh Darat Aceh Barat. 2013. Nukman Abdi. Universitas Aceh Barat. Hasil penelitian ini yaitu: komunikasi orang tua dan guru adanya pengaruh terhadap prestasi belajar anak pada Gampong Ujong Tanoh Darat Aceh Barat.Penelitian ini menggunakan metode kuantitatif berbasis metode survey ekplanatif korelasional dengan melukiskan atau menggambarkan sejumlah variable yang berkenaan dengan masalh yang diteliti. Berdasarkan hasil penelitian bahwa komunikasi orang tua dan guru berpengaruh terhadap prestasi belajar anak pada Gombong Ujong Tanoh Darat Kecamatan Meureubo Aceh Barat, yang diketahui berdasarkan deskripsi hasil perhitungan uji- $\mathrm{t}(\mathrm{t} 0)$, dengan harga nilai $\mathrm{t}_{0}$ adalah sebesar sebesar 0,8000 . Sedangkan besaran harga $\mathrm{t}$-tabel yang diperoleh dari daftar tabel distribusi t statistik pada taraf kepercayaan signifikan 0,05\% dengan derajat kebebasan $(\mathrm{dk}) \mathrm{N}=30$ adalah sebesar 1,697(PENGARUH KOMUNIKASI ORANG TUA DAN GURU SKRIPSI Oleh : NUKMAN ABDI NIM : 07C2-0220028 PROGRAM STUDI KOMUNIKASI MEULABOH , ACEH BARAT, 2013). 
1537 Pengaruh Komunikasi Guru Dan Orang Tua Terhadap Kemampuan Membaca Permulaan Siswa di Sekolah Dasar-Siti Walimah

DOI : https://doi.org/10.31004/basicedu.v5i3.966

\section{KESIMPULAN}

Hasil penelitian di atas dapat disimpulkan bahwa komunikasi guru dan orang tua secara bersama-sama telah memberikan pengaruh positif terhadap peningkatan kemampuan membaca permulaan siswa kelas 1 SDN Wilayah V Kecamatan Kalideres. Hal ini mengandung arti bahwa komunikasi guru dan komunikasi orang tua telah memberikan pengaruh yang signifikan terhadap peningkatan kemampuan membaca permulaan siswa Kelas 1 SDN Wilayah V Kecamatan Kalideres. Komunikasi guru dan orang tua dapat memberikan pengaruh yang positif terhadap kemampuan membaca permulaan siswa, karena keikutsertaan orang tua dalam menciptakan komunikasi yang intesif dengan guru dapat membantu dalam mencapai tujuan dan fungsi sekolah. Sebagai pendidik, guru dituntut untuk mampu menciptakan iklim mengajar yang kondusif, serta dapat memotivasi siswa untuk belajar. Selain itu, keterlibatan orang tua siswa pun sangat berperan aktif dalam mewujudkan tujuan pendidikan yang sudah ditetapkan. Dengan demikian, Peranan orang tua sangat penting dan dibutuhkan dalam mewujudkan keberhasilan belajar siswa, karena tujuan pembelajaran dalam pendidikan sesungguhnya tidak hanya memperhatikan mutu dari instituisi pendidikan saja, tetapi juga memperlihatkan keberhasilan keluarga dalam membentuk kepribadian dan kemandirian anak melalui interaksi sosial dalam keluarga. Komunikasi guru dan orang tua sangat diperlukan dalam meningkatkan kemampuan membaca permulaan, sebab komunikasi antara guru dan orang tua dapat meningkatkan kualitas belajar seseorang.

\section{DAFTAR PUSTAKA}

Rumidjan, Rumidjan, Sumanto, S., \& Badawi, A. (2017). Pengembangan Media Kartu Kata Untuk Melatih Keterampilan Membaca Permulaan Pada Siswa Kelas 1 Sd. Sekolah Dasar: Kajian Teori Dan Praktik Pendidikan, 26(1), 62-68. https://doi.org/10.17977/um009v26i12017p062

Hidayah, A. (2017). Jurnal Penelitian dan Penalaran Pengembangan Model TIL (The Information Literacy) Tipe the Big6 Dalam Proses Pembelajaran Sebagai Upaya Menumbuhkan Budaya Literasi Di Sekolah. Pena, 4, 623-635.

Iii, B. A. B., \& Penelitian, A. M. (2015). Indra Kharisman, 2015 PENGARUH AKTIVITAS OUTDOOR EDUCATION TERHADAPb KEPERCAYAAN DIRI SISWA Universitas Pendidikan Indonesia| repository.upi.edu| perpustakaan.upi.edu 39.39-56.

Marina, D. (2015). Pengaruh Pemeriksaan Pajak Terhadap Kepatuhan Wajib Pajak Badan (Suatu Studi Pada Kantor Pelayanan Pajak Madya Bandung). 45-71.

Nurma Annisa Azzahra, Hardika, D. K. (2019). Pola Komunikasi Guru Dalam Pembelajaran Anak Usia Dini. Pendidikan, 4(2), 37-142. https://doi.org/SHERPA/RoMEO-Google Scholar-IPI

Pedagogik, J. R. (2020). Dwija cendekia. 4(2), 186-196.

PENGARUH KOMUNIKASI ORANG TUA DAN GURU SKRIPSI Oleh : NUKMAN ABDI NIM : 07C2 O220028 PROGRAM STUDI KOMUNIKASI MEULABOH , ACEH BARAT. (2013).

Program, M., Magister, S., Komunikasi, I., \& Undip, F. (2014). Komunikasi Orangtua-Anak dalam Pengambilan Keputusan Pendidikan. Interaksi: Jurnal Ilmu Komunikasi, 3(2), 112-122. https://doi.org/10.14710/interaksi.3.2.112-122

Rachmawati, A., \& N, F. S. (2020). MENGGUNAKAN MEDIA KARTU BERGAMBAR PADA SISWA KELAS B SCHOOL FOR REFUGEES DOMPET DHUAFA. 10(23), 21-26.

Rachmawaty, M. (2017). Penigkatan Kemampuan Membaca Permulaan Melalui Dinding Kata (Word Wall). Jurnal INDRIA (Jurnal Ilmiah Pendidikan Prasekolah Dan Sekolah Awal), 2(1), $28-44$. https://doi.org/10.24269/jin.v2n1.2017.pp28-44

Rahman, B., \& Yogyakarta, U. N. (2014). Peningkatan keterampilan membaca permulaan melalui media 
1538 Pengaruh Komunikasi Guru Dan Orang Tua Terhadap Kemampuan Membaca Permulaan Siswa di Sekolah Dasar-Siti Walimah

DOI : https://doi.org/10.31004/basicedu.v5i3.966

flashcard pada siswa kelas $i$ sdn bajayau tengah 2 improving early reading skill through flashcard media in 1. 2, 127-137.

Susilana, R. (2015). Modul Populasi dan Sampel. Modul Praktikum, 3-4. http://file.upi.edu/Direktori/DUALMODES/PENELITIAN_PENDIDIKAN/BBM_6.pdf

Tjoe, J. O. L. (2013). Peningkatan kemampuan membaca permulaan melalui pemanfaatan multimedia. Jurnal Pendidikan Anak Usia Dini, 7, 17-48.

Triwardhani, I. J., Trigartanti, W., Rachmawati, I., \& Putra, R. P. (2020). Strategi Guru dalam membangun komunikasi dengan Orang Tua Siswa di Sekolah. Jurnal Kajian Komunikasi, 8(1), 99. https://doi.org/10.24198/jkk.v8i1.23620

Vinet, L., \& Zhedanov, A. (2011). A "missing" family of classical orthogonal polynomials. Journal of Physics A: Mathematical and Theoretical, 44(8), 1-9. https://doi.org/10.1088/1751-8113/44/8/085201

Wisman, Y. (2017). Komunikasi Efektif Dalam Dunia Pendidikan. Jurnal Nomosleca, 3(2), 646-654. https://doi.org/10.26905/nomosleca.v3i2.2039 